\title{
Diatom species composition and indices for determining the ecological status of coastal Mediterranean Spanish lakes
}

\author{
Beatriz Antón-Garrido ${ }^{1 *}$, Susana Romo ${ }^{1} \&$ María José Villena ${ }^{2}$ \\ ${ }^{1}$ Departamento de Ecología, Edificio de Investigación, Universitat de València, Campus Burjasot, E-46100 Burjasot, Spain; \\ beanga@alumni.uv.es; Susana.Romo@uv.es \\ ${ }^{2}$ Laboratorios Tecnológicos de Levante, S.L., E-46980 Paterna, Spain; mjvillen@uv.es
}

\begin{abstract}
Antón-Garrido, B., Romo, S. \& Villena, M.J. 2013. Diatom species composition and indices for determining the ecological status of coastal Mediterranean Spanish lakes. Anales Jard. Bot. Madrid 70(2): 122-135.

Diatom indices have been used and tested mainly for assessing the ecological status of rivers and deep lakes, but there are scarce studies that determine their effectiveness in shallow lakes and in coastal Mediterranean lakes. This study evaluates the validity of several common diatom indices (SPI, BDI, CEC and TDIL) for the determination of the ecological quality of three coastal lakes (Valencia, Spain) and presents descriptions and ecological data of the main diatom species recorded. Diatom samples were collected from phytobenthos, both from epiphyton of the dominant submerged macrophytes and the sediment. The ecological status of the systems was determined according to different physico-chemical variables and was compared with the results obtained from epiphytic diatom communities. The results showed discrepancies among diatom indices and also with the state determined by the environmental variables. The effectiveness of the indices depended on the number of species assessed for each index with respect to the total species recorded and the suitability of the weight assigned to each species. The results reveal the need to gather more information about the composition and ecology of the diatoms and microalgae characteristic of coastal Mediterranean standing waters. This work contributes to their better knowledge.
\end{abstract}

Keywords: Bacillariophyceae, bioindicators, epiphyton, dune ponds, water quality, WFD.

\section{INTRODUCTION}

The Water Framework Directive requires to the European Union countries to monitor and control the ecological status of their water bodies, as an essential way

to protect, improve and conserve the EU aquatic systems (WFD, Directive 2000/60/EC). Among the proposed bioindicators, benthic diatoms are one of the most relevant groups for the monitoring and control of the ecological status of aquatic ecosystems. These organisms are used in bioindication studies, by means of autoecological indices based on the relative abundance of each taxon, their sensitivity to environmental factors and their ecological distribution (Della Bella \& Mancini, 2009; Cejudo-Figueiras, 2011). Most of the implemented protocols using diatom indices for the assessment of the water quality have been focused on rivers and deep lakes, mainly located in Central Europe (DOCE, 2008). However, there is less information about its application on shallow lakes (Kitner \& Poulickova, 2003; Blanco \& al., 2004; StengerKovács \& al., 2007), and particularly on Mediterranean shal-

\section{Resumen}

Antón-Garrido, B., Romo, S. \& Villena, M.J. 2013. Composición e índices de especies de diatomeas para la determinación del estado ecológico de las lagunas litorales mediterráneas de España. Anales Jard. Bot. Madrid 70(2): 122-135 (en inglés).

Los índices de diatomeas han sido aplicados y contrastados principalmente en la evaluación del estado ecológico de los sistemas lóticos y lagos profundos, pero son escasos los estudios sobre su eficacia en lagos someros y lagunas litorales mediterráneas. Este trabajo evalúa la validez de varios índices conocidos de diatomeas (IPS, IBD, CEE y TDIL) para la determinación de la calidad ecológica de tres lagunas litorales (Valencia, España) y presenta las descripciones y datos ecológicos de las principales especies de diatomeas registradas. Las muestras de diatomeas se recogieron del fitobentos, tanto del epifiton desarrollado sobre las especies de macrófitos sumergidos dominantes, como del sedimento. El estado ecológico de las lagunas se determinó a partir de diferentes variables físico-químicas y fue contrastado con los resultados obtenidos a partir de las comunidades de diatomeas epifíticas. Los resultados mostraron discrepancias entre los índices diatomológicos y también con respecto al estado diagnosticado por las variables ambientales. La efectividad de los índices dependió del número de especies evaluadas por cada índice con respecto al total de especies registradas y la idoneidad del valor indicador y de sensibilidad asignado a cada especie. Los resultados ponen de manifiesto la necesidad de ampliar el conocimiento sobre la composición y la ecología de las diatomeas y microalgas que caracterizan las lagunas litorales mediterráneas. Este trabajo contribuye a su mejor conocimiento.

Palabras clave: Bacillariophyceae, bioindicadores, epifiton, lagunas interdunares, calidad del agua, DMA.

low lakes, even though there is evidence that their ecology differ from that reported in the temperate zone (Romo \& al., 2004; Moss \& al., 2004). Moreover, among the indices, there is a wide heterogeneity in their database and about the diatom species that they consider. Furthermore, their effectiveness varies depending on the ecosystem type and the eco-region (Cejudo-Figueiras, 2011; Álvarez-Blanco \& al., 2011, 2012). Nowadays, the information about the use of diatoms indices in Mediterranean standing waters is scarce. Recently, the approach of adapting diatom indices commonly used in rivers to establish the ecological status of some inland waters in the Iberian Peninsula has been carried out (Blanco \& al., 2004; Cejudo-Figueiras \& al., 2010). However, similar studies of diatom indices application in coastal lakes are lacking. For example, coastal water bodies have higher salinity ranges than inland freshwaters, as well as different morphology and environmental impacts on their catchment areas.

This work tests the usefulness of several well-known diatom indices in some coastal shallow lakes. The study is a first approach to the evaluation of its suitability in the determina- 
tion of the ecological status in this type of ecosystems for the implementation of the WFD. Furthermore, it reports detailed taxonomic descriptions and ecological data of the main diatom species, in order to contribute to the knowledge of the characteristic diatom flora inhabiting this type of ecosystems.

\section{MATERIAL AND METHODS}

The study was carried out in three interdunar, shallow and permanent lakes located in the Natural Park of Albufera and named as, Mata del Fang (MFPNS) and Lagunas del Canyar (CNP1 and CNP3) (Fig. 1). Their hydrological dynamic is characteristic of this type of Mediterranean water bodies, with seasonal fluctuations in the water level mainly during summer and water inputs from rain, groundwater and saline spray. They are surrounded by helophytic vegetation (Phragmites, Thypha, Juncus and Scirpus) and their bottom was covered by charophyte meadows, growing on a sand-silty substrate.

The ponds were sampled on $15^{\text {th }}$ October 2009. An integrated water sample from each pond was collected by sampling and mixing the water from several points across the pond and subsamples were used for water chemical analyses and other determinations. Depth, temperature, $\mathrm{pH}$, conductivity and oxygen concentration in the water were determined in situ. Dissolved nitrogen and phosphorus concentrations, as well as phytoplanktonic chlorophyll $a$ were analyzed according to standard methods (APHA, 1992).

Samples of epiphytic and benthic microalgae were also collected. Epiphyton samples were taken from the dominant macrophytes (Chara spp.). Epiphytic algae were detached from the plant by shaking in a standardized water volume that was fixed with lugol solution for further studies and taxo- nomic identification (Zimba \& Hopson, 1997). Benthic algae were sampled by collecting a total of 20 sediment surface cores (upper $2 \mathrm{~cm}$ ) taken randomly all over each pond. The cores were integrated into a sample per pond and frozen for later analyses. Diatom samples were digested with hydrogen peroxide according to standard protocols (UNE-ENE 13946, 2004). Identification and counting were made from permanent preparations mounted with Naphrax ${ }^{\circledR}$ and at least 400 valves were counted for each sample at $\times 1000$ magnification. In addition, scanning electron microscope (SEM) analyses were carried out for accurate identification of some species. Morphometry of the dominant diatoms was determined by measuring length and width of a minimum of 20 individuals. The determination of the different taxa was carried following specific references: Germain, 1981; Krammer \& LangeBertalot, 1991a, b, 1997a, b, 2000; Prygiel \& Coste, 2000; CHD, 2010.

The diatom indices SPI (Specific Polluosensitivity Index, CEMAGREF, 1982), BDI (Biological Diatom Index, Lenoir \& Coste, 1996) and CEC (Comission for Economical Community Index, Descy \& Coste, 1990) were calculated for the epiphyton by means of the software OMNIDIA version 5.1 (Lecointe \& al., 1993). Only those taxa with relative abundance higher than $5 \%$ were considered in their calculation. The TDIL index was calculated according to Stenger-Kovács $\&$ al. (2007). These indices were selected for their wide use in Spain, as well as in other European countries (Blanco \& al., 2008) and TDIL for being specific on shallow lakes. The ecological status of each pond was also assessed by physico-chemical metrics according to their habitat typology of permanent, coastal, interdunar lakes (BOE, 2008; CEDEX, 2010a, b).
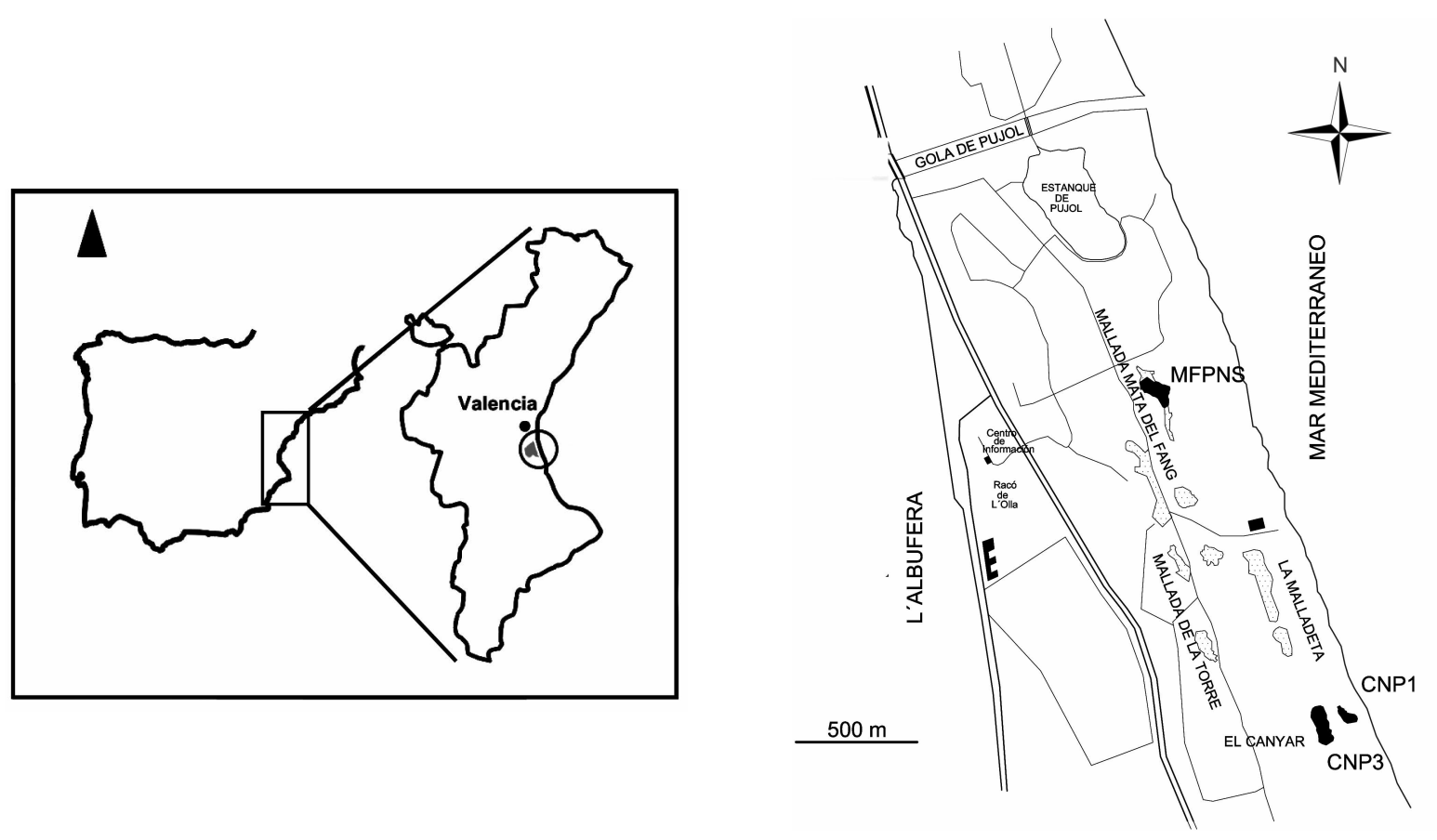

Fig. 1. Study area and the location of the ponds (in grey). Central map coordinates: $39^{\circ} 20^{\prime} 22.35^{\prime \prime} \mathrm{N}, 0^{\circ} 18^{\prime} 52.01^{\prime \prime} \mathrm{W}$. 


\section{RESULTS}

The studied lakes were oligohaline, with almost saturated oxygen concentrations, neutral-alkaline $\mathrm{pHs}$ and water transparency reaching the bottom (Table 1). Phosphate values were low and similar in the three ponds, while nitrate was the main form of soluble inorganic nitrogen (Table 1). Ammonium and nitrite were below the detection level of the analytical methods. Mata del Fang (MFPNS) recorded the highest values of nitrate and phytoplanktonic chlorophyll $a$ (Table 1). CNP1 had concentrations of phytoplanktonic chlorophyll a slightly higher than CNP3, even though their proximity (Fig. 1) and similar nutrient concentrations (Table 1).

The ecological status assessment of the ponds by using threshold values for $\mathrm{pH}$, conductivity and mainly phytoplanktonic chlorophyll $a$ concentration are shown in Table 2 .

The diatom indices showed discrepancies with the ecological states determined by the environmental variables (Tables $2,3)$. Furthermore, the quality assessment also differed between the indices, mainly depending on the number of recorded diatom species considered by each index in their calculation (Table 3). The most efficient diatom indices and those which considered higher number of the recorded diatom species were SPI and BDI (Table 3). However, com- pared to the environmental metrics, they seemed to overestimate water quality for MFPN, while underestimated that of CNP3 (Tables 2,3). By contrast, CEC and TDIL indices were less efficient and they took into account lower percentages of the identified diatom species (Table 3).

\section{Diatom species description}

A total of 63 species of diatoms belonging to 30 genera were identified for the epiphytic and benthic communities of the three sampled lakes. The identification was carried out to species level in 60 cases and to genus level in 3 cases (Table 4). In general, most of the identified species had ecological requirements related to alkaline $\mathrm{pH}$, tolerance to salinity and a wide range of nutrient concentrations. It was remarkable the abundance and presence in the three study lakes of species related to brackish environments, such Halamphora cf. sydowii and those species belonging to the genus Mastogloia, as well as other species, such as Seminavis pusilla, Fragilaria gracilis and Nitzschia elegantula (Table 4). In the epiphyton, Seminavis pusilla co-dominated in abundance, together with Rhopalodia gibba var. gibba in CNP3 and with Encyonema sp. in CNP1 and MFPNS (Fig. 2).
MFPNS-Epiphyton

$\begin{array}{llllll}0 & 20 & 40 & 60 & 80 & 100\end{array}$

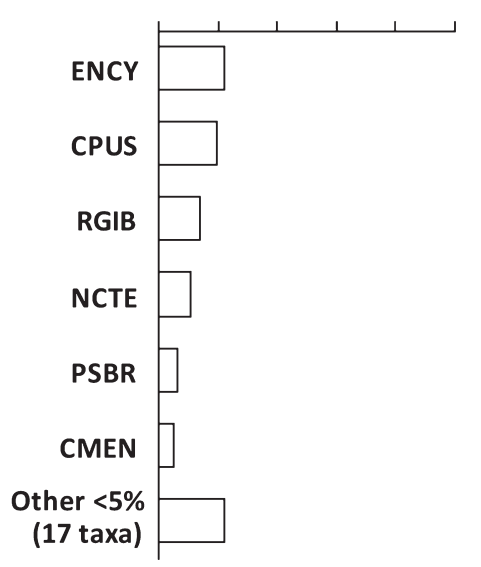

MFPNS-Sediment

$\begin{array}{llllll}0 & 20 & 40 & 60 & 80 & 100\end{array}$

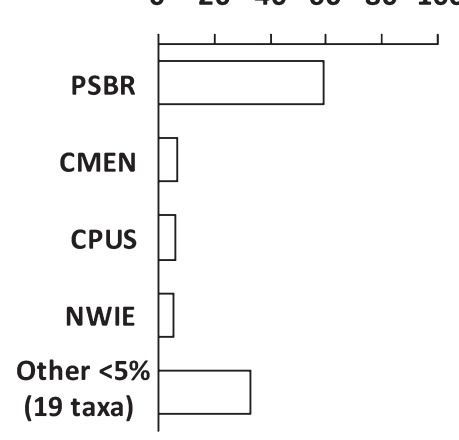

CNP1-Epiphyton

$\begin{array}{llllll}0 & 20 & 40 & 60 & 80 & 100\end{array}$

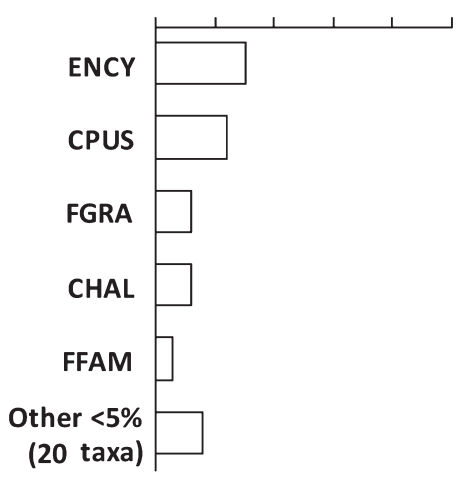

CNP1-Sediment

$0 \quad 20406080100$

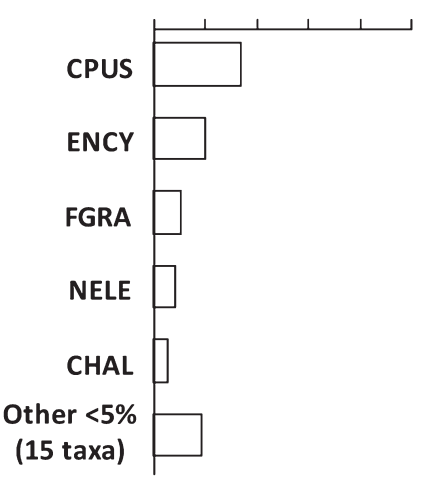

CNP3-Epiphyton

$0 \quad 20406080100$

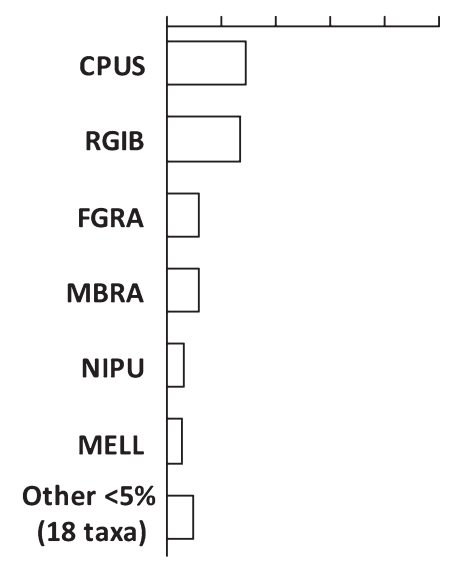

CNP3-Sediment

$0 \quad 2040 \quad 6080100$

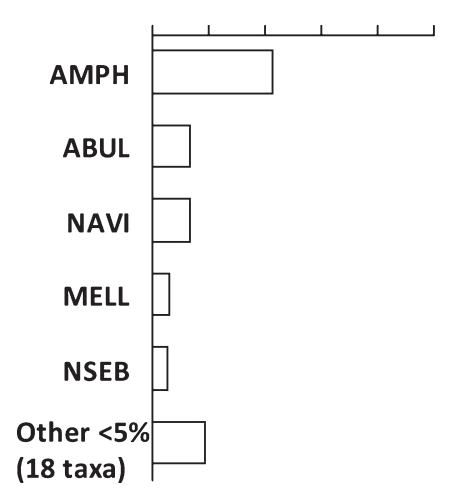

Fig. 2. Percentage of relative abundance of the main epiphytic and benthic diatoms identified in the study. Abbreviated taxa names according to Table 4. 
Table 1. Morphometric and physico-chemical characteristics of the study lakes.

\begin{tabular}{|c|c|c|c|c|c|c|c|c|c|}
\hline & $\begin{array}{c}\text { Area } \\
\text { (ha) }\end{array}$ & $\begin{array}{c}\text { Maximum and mean } \\
\text { depth }(\mathrm{cm})\end{array}$ & $\begin{array}{l}\text { Conductivity } \\
\qquad\left(\mathrm{mS} \mathrm{cm}^{-1}\right)\end{array}$ & $\begin{array}{l}\mathrm{T}^{\mathrm{a}} \\
\left({ }^{\circ} \mathrm{C}\right)\end{array}$ & $\mathrm{pH}$ & $\begin{array}{c}\mathbf{O}_{2} \\
\left(\mathrm{mg} \mathrm{L}^{-1}\right)\end{array}$ & $\begin{array}{l}\mathrm{NO}_{3}-\mathrm{N} \\
\left(\mathrm{mg} \mathrm{L}^{-1}\right)\end{array}$ & $\begin{array}{l}\mathbf{P}^{-\mathrm{PO}_{4}} \\
\left(\mathrm{mg} \mathrm{L}^{-1}\right)\end{array}$ & $\begin{array}{l}\text { Chl-a } \\
\left(\mu \mathrm{g} \mathrm{L}^{-1}\right)\end{array}$ \\
\hline MFPNS & 0.50 & $200(90)$ & 2.17 & 22.5 & 8.24 & 9.47 & 0.24 & 0.01 & 16.5 \\
\hline CNP1 & 0.10 & $100(70)$ & 1.98 & 20.2 & 7.80 & 5.17 & 0.17 & 0.01 & 8.9 \\
\hline CNP3 & 0.88 & $200(91)$ & 1.58 & 21.7 & 8.32 & 7.08 & 0.20 & 0.01 & 1.6 \\
\hline
\end{tabular}

Table 2. Ecological status assessment of the study lakes based on some environmental variables according to CEDEX (2010 a, b).

\begin{tabular}{lcccc}
\hline & & Chemical status & Biological status & \multirow{2}{*}{ Ecological status } \\
\cline { 2 - 4 } & pH & Conductivity & Chlorophylla & Moderate \\
MFPN & Good or superior & High & Moderate & Good \\
CNP1 & Good or superior & High & Good & High \\
CNP3 & Good or superior & High & High & \\
\hline
\end{tabular}

Table 3. Diatom indices SPI, BDI, CEC and TDIL with indication of the percentage of identified epiphytic diatoms species considered by each index and the ecological status assessment for the study lakes.

\begin{tabular}{|c|c|c|c|c|c|c|c|c|}
\hline & $\begin{array}{l}\text { SPI/Ecological } \\
\text { status }\end{array}$ & $\begin{array}{c}\% \\
\text { species } \\
\text { SPI }\end{array}$ & $\begin{array}{l}\text { BDI/Ecological } \\
\text { status }\end{array}$ & $\begin{array}{c}\% \\
\text { species } \\
\text { BDI }\end{array}$ & $\begin{array}{l}\text { CEC/Ecological } \\
\text { status }\end{array}$ & $\begin{array}{c}\% \\
\text { species } \\
\text { CEC }\end{array}$ & $\begin{array}{l}\text { TDIL/Ecological } \\
\text { status }\end{array}$ & $\begin{array}{c}\% \\
\text { species } \\
\text { TDIL }\end{array}$ \\
\hline MFPNS & 16.4/Good & 100 & 13.7/ Good & 74 & 11.5/Moderate & 57 & 2.1/Moderate & 61 \\
\hline CNP1 & $16.5 / \mathrm{Good}$ & 92 & $15.2 / \mathrm{Good}$ & 76 & 13.2/Good & 60 & 1.5/Poor & 64 \\
\hline CNP3 & 16.6/Good & 82 & $14.4 / \mathrm{Good}$ & 71 & 12.6/Moderate & 59 & 1.9/Poor & 65 \\
\hline
\end{tabular}

The diatom communities in the sediment had a species composition and abundance distribution similar to that of the epiphyton in CNP1, while in CNP3 and MFPNS there were more differences, although most of the recorded species appeared in both substrates (Fig 2, Table 4). In MFPNS the benthic microalgal community was dominated by Pseudostaurosira brevistriata, while several Halamphora species predominated in CNP3.

A catalogue of the main diatom species found with a relative abundance higher than $5 \%$ is presented below, together with a description of their taxonomic characteristics. Light (LM) and scanning electron microscope (SEM) photographs were taken from the epiphytic and benthic samples of the aquatic study systems to illustrate each taxon. The biometric ranges provided correspond to individuals measured in the samples.

Class Bacillariophyceae

Order Bacillariales

Family Bacillariaceae Ehrenberg

Nitzschia elegantula Grunow [LM: Fig. 3: 35-37]

(Nitzschia elegantula Grunow in van Heurck, 1881: pl. 69, fig. 22a)

Nitzschia microcephala var. elegantula (Grunow) van Heurck, 1885

Length 11.5-14.8 $\mu \mathrm{m}$, breadth 3-3.7 $\mu \mathrm{m}$. Valves small, linear-lanceolate. Capitate ends with a central constriction in one side. Visible striae 13/10 $\mu \mathrm{m}$, strongly punctated. Marginal raphe system with 6-7 fibulae/10 $\mu \mathrm{m}$.

Ecology and distribution: characteristic of brackish waters, widely distributed in coastal waterbodies of the Mediterranean. In this study, recorded in all the lakes (Table 4).
Nitzschia pusilla (Kützing) Grunow [LM: Fig. 4: 24-28; SEM: Fig. 7:2]

(Nitzschia pusilla Grunow, 1862: 579; pl. 28/12, fig.11)

Nitzschia amphioxys var. pusilla (Grunow) Mayer, 1913

Hantzschia amphioxys var. pusilla (Grunow) Dippel, 1905

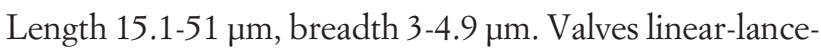
olate with variable size. Rounded or subrostrate apices. Striae not visible to light microscope. Medium-size fibulae equidistants in the central area, $16-20 / 10 \mu \mathrm{m}$, pores dot-like to approximately square.

Ecology and distribution: broad distribution, circumneutral, fresh-brackish, oligo-eutrophic- $\beta$-mesosaprobic waters. In this study, it was observed in CNP3 and MFPNS, mainly living on the vegetation.

Order Cymbellales

Family Cymbellaceae Greville

Encyonema sp. Kützing [LM: Fig. 3: 16-25; SEM: Fig. 6: 4] (Kützing, F.T., 1834: 529-620, Plates XIII-XIX [79 figs.])

Length 12.3-19.7 $\mu \mathrm{m}$, breadth 4.2-5 $\mu \mathrm{m}$. Dorsiventral valves with rounded apices. Dorsal margin bent, ventral more or less straight or very slightly convex. Axial narrowly area, wider in the center toward the dorsal side. Raphe straight with central endings bent dorsally and apical ends bent ventrally, central nodules clearly marked. Striae parallel to slightly radial in the center, 20 dorsal and 19-20 ventral/10 $\mu \mathrm{m}$, often with a shorter central stria on the dorsal side. Striae pores are unclearly seen by LM but visible by SEM, $5 / 1 \mu \mathrm{m}$. This species deserves a more extensive taxonomic study, due to its distinct features with respect to other related Encyonema species. 


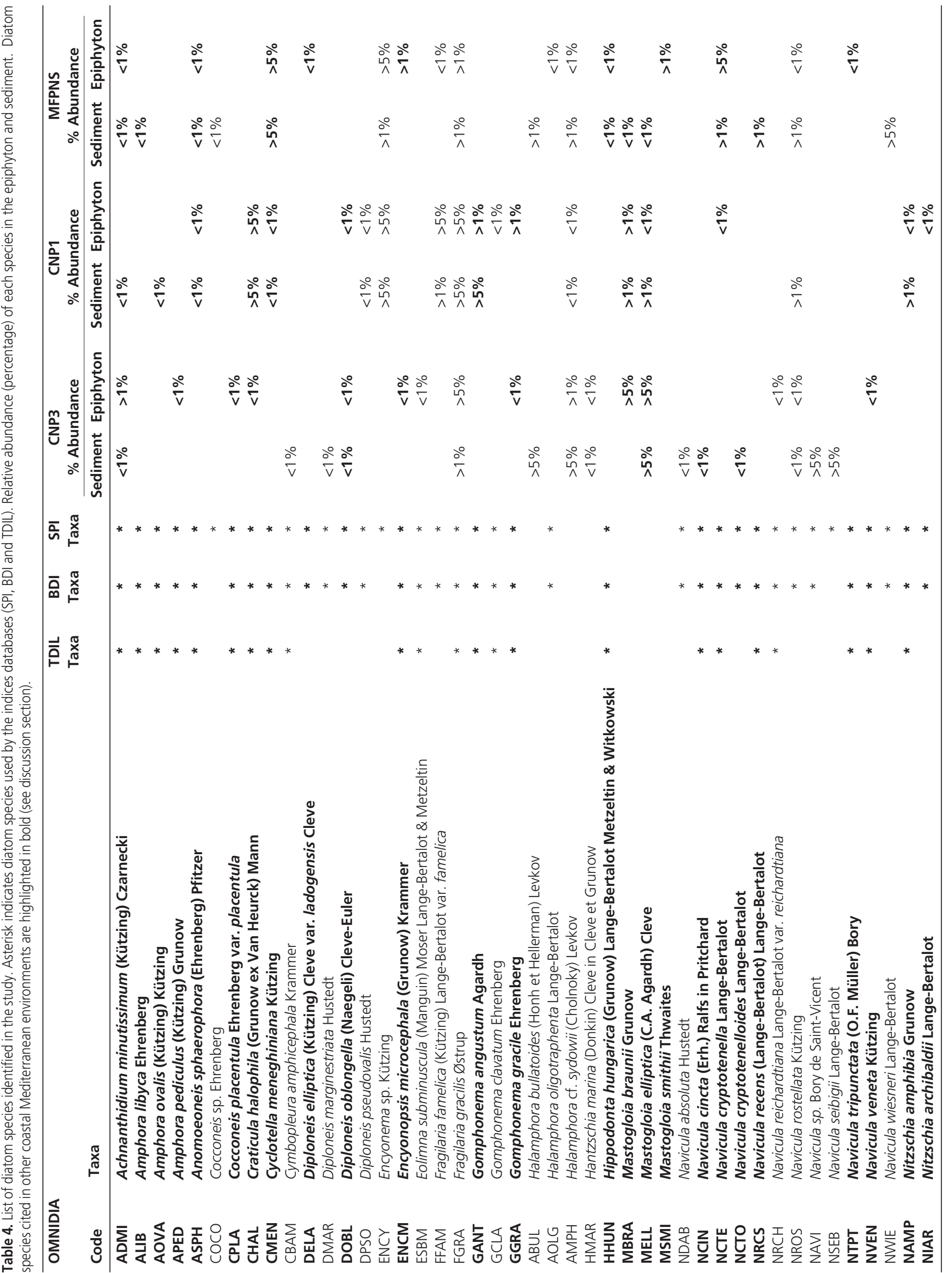




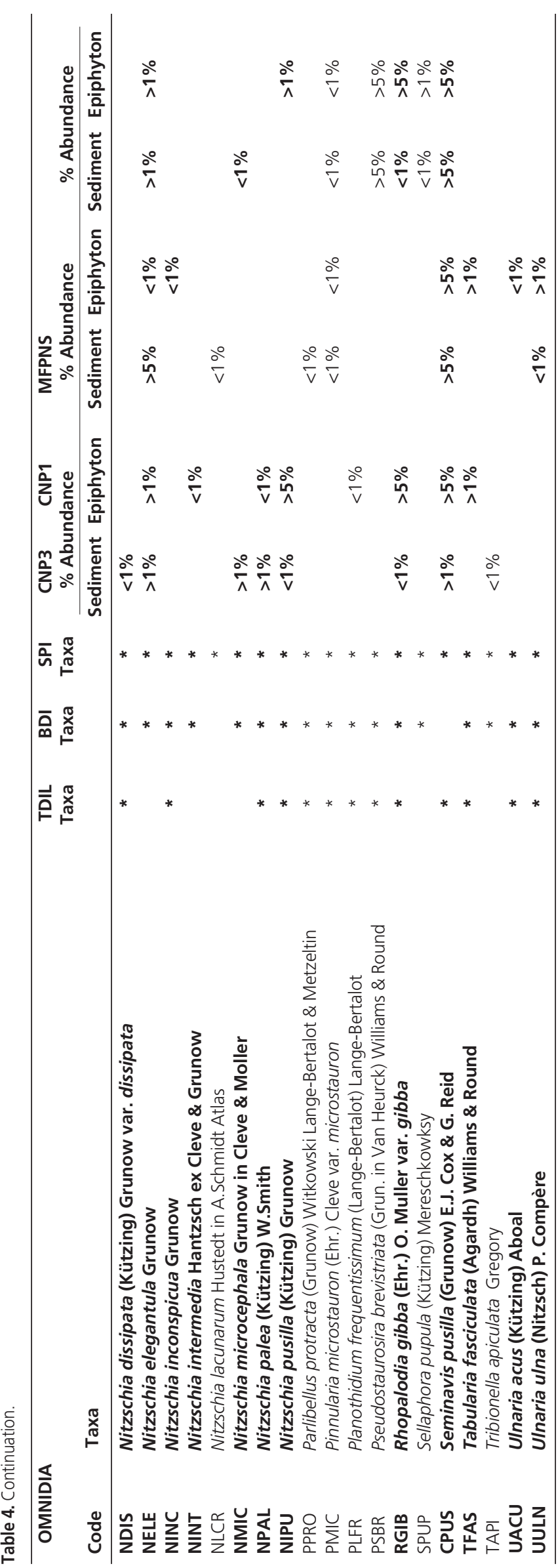

Ecology and distribution: in this study, it was mainly observed in the epiphyton and also in the sediment of CNP1 and MFPNS (Table 4).

Order: Fragilariales

Family: Fragilareaceae Greville

Fragilaria famelica var. famelica (Kützing) Lange-Bertalot [LM: Fig. 4: 14-19; SEM: Fig. 7: 5]

(Fragilaria famelica (Kützing) Lange-Bertalot, 1980: 749) Synedra famelica Kützing, 1844

Length 33.4-53.5 $\mu \mathrm{m}$, breadth 2.1-2.7 $\mu \mathrm{m}$. Valves elongated and nearly linear. Slightly wider in the center with rounded apices. Visible and marked parallel striae, very narrow central pseudoraphe, $16-18 / 10 \mathrm{~m}$.

Ecology and distribution: alkalophilic, fresh-brackish, mesotrophic oxygenated waters. In this study, it was recorded in CNP1 (epiphyton and sediment) and in low number in the epiphyton of MFPNS (Table 4).

Fragilaria gracilis Oestrup [LM: Fig. 3:38-45; SEM: Fig. 7: 4] (Fragilaria gracilis Østrup, 1910: 190, pl. V: fig. 117) Fragilaria capucina var. gracilis (Oestrup) Hustedt

Length 14.5-31.7 $\mu \mathrm{m}$, breadth 1.8-2.1 $\mu \mathrm{m}$. Valves narrowly linear, linear-lanceolate. Parallel striae along the valve margin 22-24/10 m, formed by a single pore (SEM). Pseudorafe well defined, with a rectangular central area. Apiculated apices in small individuals.

Ecology and distribution: circumneutral, fresh-brackish, eutrophic- $\alpha$-mesosaprobic waters. In this study, it was mainly present in the epiphyton of MFPNS, CNP1 and CNP3 (Table 4).

Pseudostaurosira brevistriata (Grun. in Van Heurck) Williams \& Round [LM: Fig. 3: 46-50]

(Pseudostaurosira brevistriata (Grunow) D.M.Williams \& Round ,1987: 276, figs 28-31)

Fragilaria brevistriata Grunow, 1885

Length 8.2-11.1 $\mu \mathrm{m}$, breadth 3.7-5.4 $\mu \mathrm{m}$. Valves of small size, lanceolate-elliptical with rounded apices. Thick and short striae all over the margin $14-15 / 10 \mu \mathrm{m}$, with a lanceolate to linear-lanceolate pseudoraphe. Visible pores by SEM, 3 $4 /$ striae.

Ecology and distribution: periphytic, alkalophilic, tolerant to a wide range of conductivity, oligosaprobic-oligo-eutrophic waters. Frequently cited in the Iberian peninsula. In this study, it was abundant in the sediment of MFPNS (Table 4, Fig. 2).

Order Mastogloiales

Family Mastogloiaceae Mereschkowsky

Mastogloia braunii Grunow [LM: Fig. 4:3-6; SEM: Fig. 7:6] (Mastogloia braunii Grunow, 1863: 156; pl.13, fig.2)

Length 31.4- 63.7 $\mu \mathrm{m}$, breadth 14.6-18.3 $\mu \mathrm{m}$. Larg lanceolate valves, with variable length and cuneiform apices. Sinuous raphe, proximal end at the beginning of the central area, 


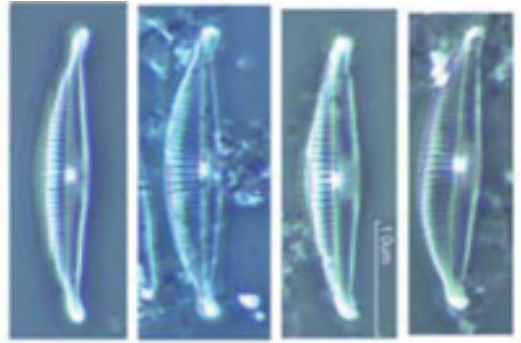

1-4
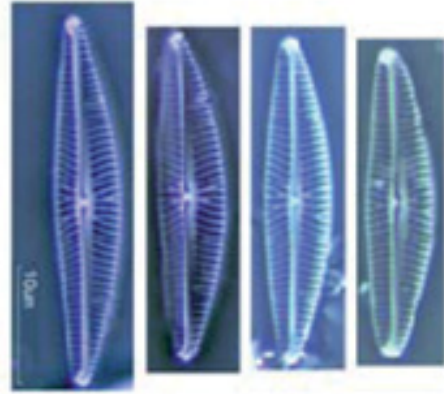

12- 15
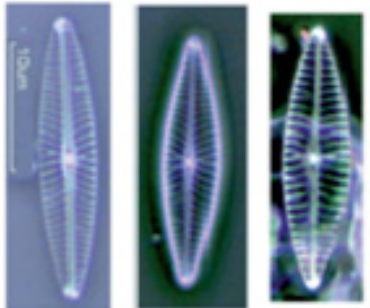

26-29
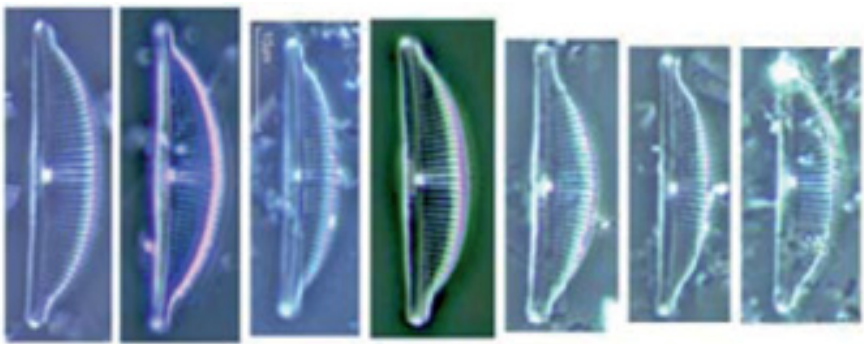

5-11
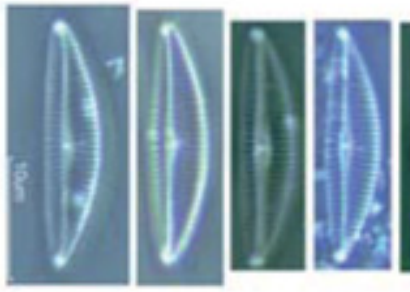

16-25
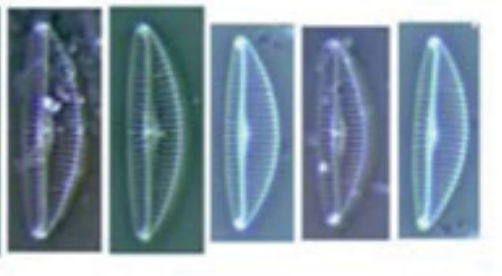

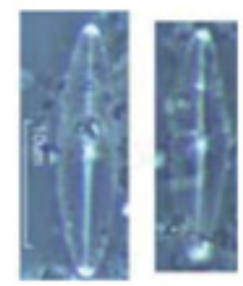

30-31

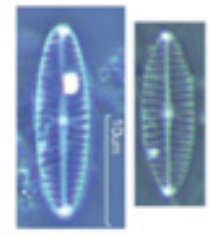

$32-33$

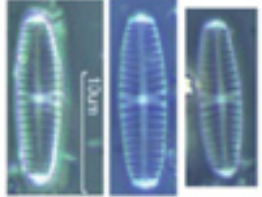

34-36
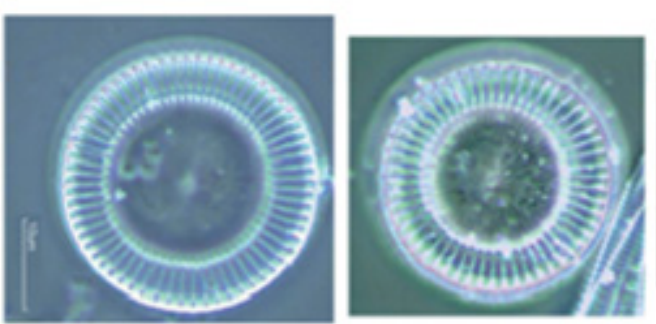

$37-40$

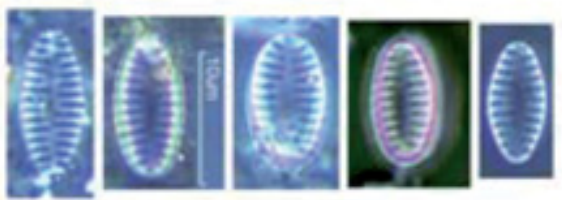

49-53
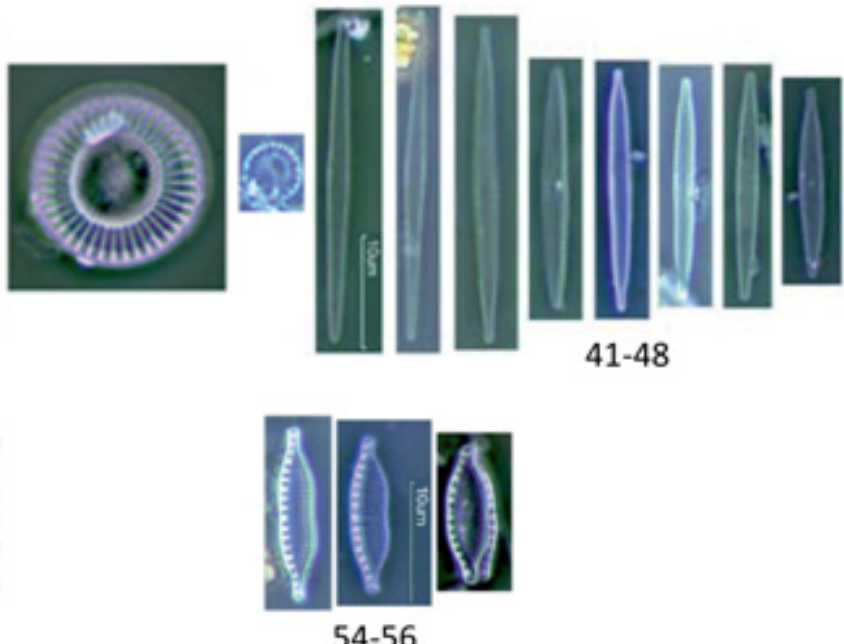

Fig. 3. Dominant species (abundance > 5\%) LM: ×1000. Images 1-56: 1-4, Halamphora bullatoides; 5-11, Halamphora cf. sydowii; 12-15, Navicymbula pusilla; 16-25, Encyonema sp.; 26-29, Navicula cryptotenella; 30-31, Navicula sp.; 32-33, Navicula wiesneri; 34-36, Navicula seibigii; 37-40, Cyclotella meneghinian,; 41-48, Fragilaria gracilis; 49-53, Pseudostaurosira brevistriata; 54-56, Nitzschia elegantula. Scale bar: $10 \mu \mathrm{m}$.

while the distal end hooked. Axial narrowly area, with lateral prolongations in $\mathrm{H}$ along the longitudinally valve and parallel to the raphe, leaving a central hyaline zone with a rectangular transversal form. Bluntly doted striae, parallel distribution in the central area and convergent in the mid-distal part (13) $17 / 10 \mu \mathrm{m}$. Lateral central chambers larger than in the rest.
Ecology and distribution: epiphytic, alkalophilic and brackish waters. Broad distribution in coastal Mediterranean water bodies. It was recorded in all the lakes of this study (Table 4).

Mastogloia elliptica (C.A. Agardh) Cleve [LM: Fig. 4: 7-13; SEM: Fig. 7: 7] 

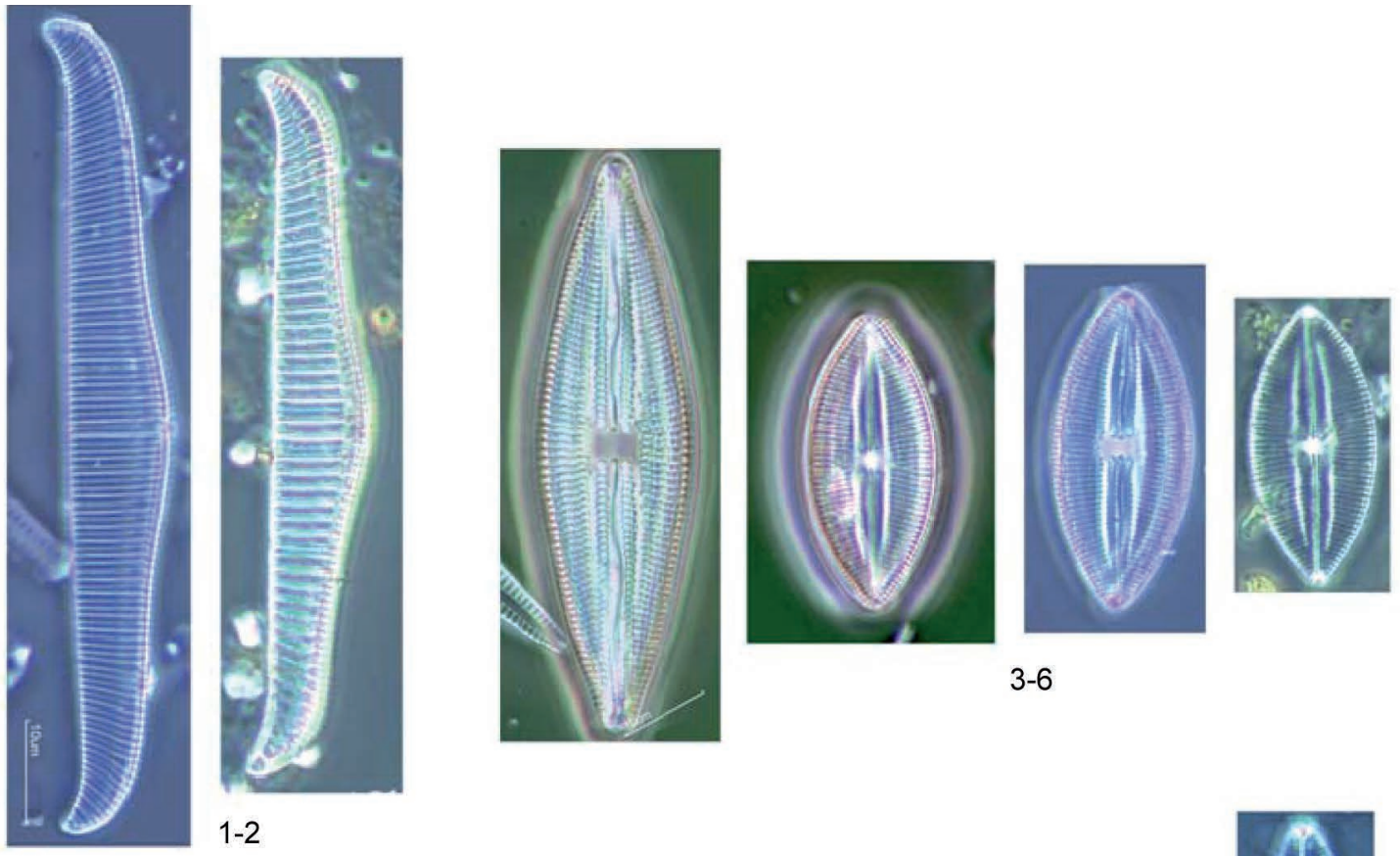

3-6
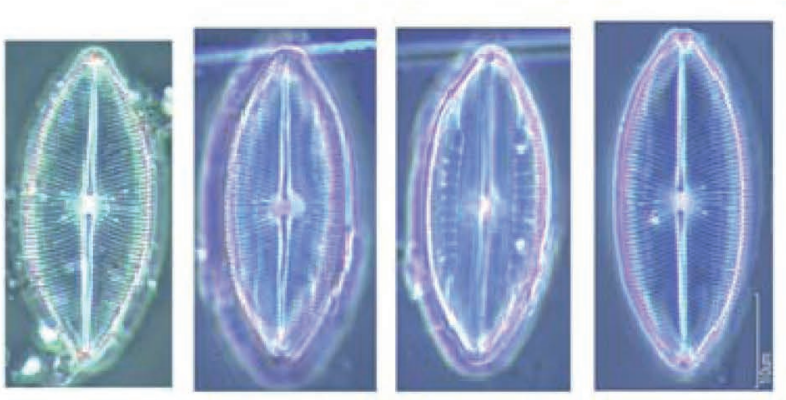

$7-13$
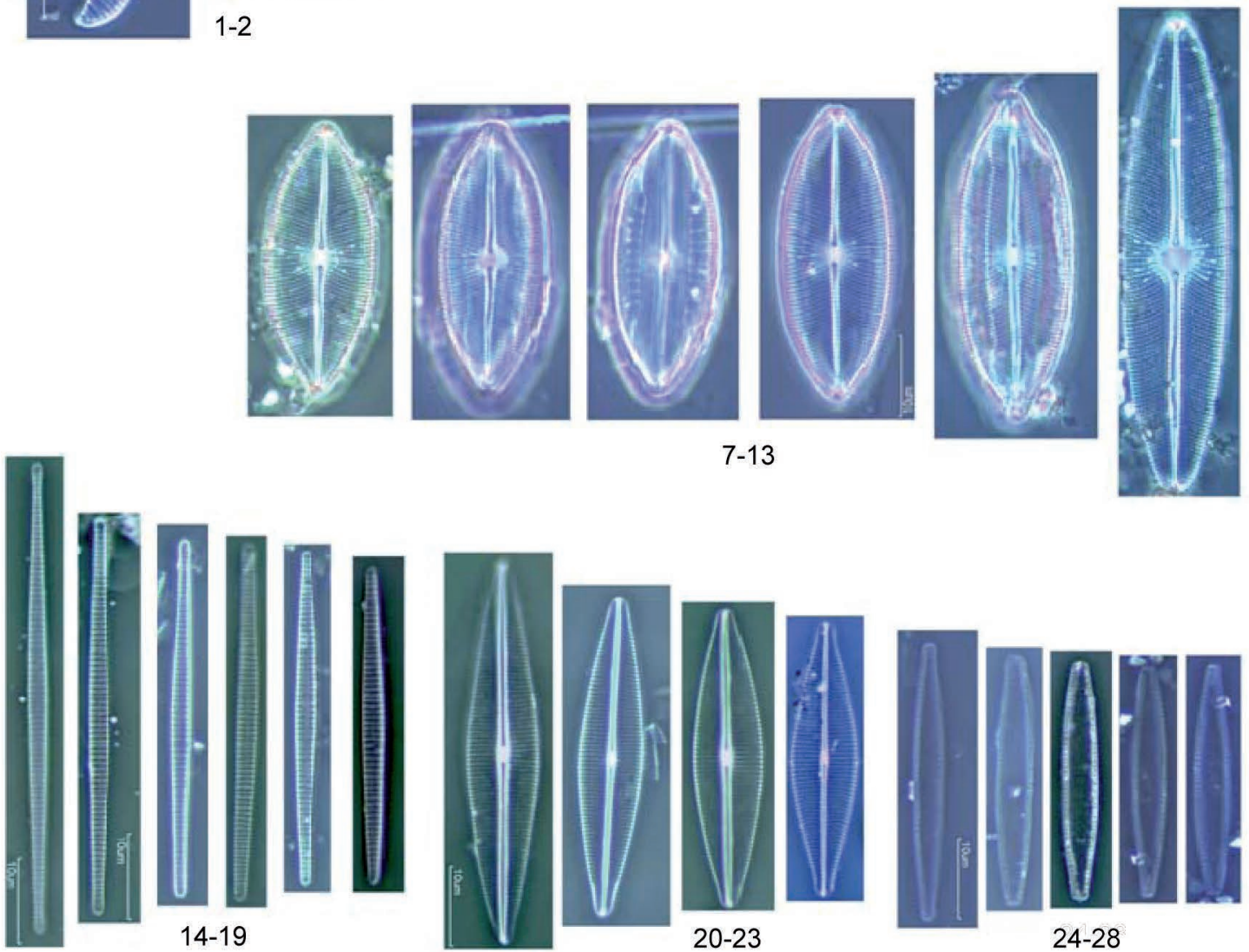

Fig. 4. Dominant species (abundance > 5\%) LM: ×1000. Images 1-28: 1-2, Rhopalodia gibba var. gibba; 3-6, Mastogloia braunii; 7-13, Mastogloia elliptica; 14-94, Fragilaria famelica var. famelica; 20-23, Craticula halophila; 24-28, Nitzschia pusilla. Scale bar: 10 um.

(Mastogloia elliptica (C. Agardh) Cleve in Schmidt \& al., 1893: 185, fig. 24-27)

Amphora elliptica (Agardh) Kützing, 1844

Mastogloia dansei var. elliptica (C. Agardh) Grunow, 1880

Frustulia elliptica C. Agardh, 1824

Length 31.2-40.6 $\mu \mathrm{m}$, breadth 12.6-14.6 $\mu \mathrm{m}$. Valves ellipti- cal-linear-lanceolate, axial narrow and central rounded. Sinuous raphe. Striae 18-19/10 $\mu \mathrm{m}$, clearly punctate, radial in the center and alternating long and short in this area. Lateral chambers along the margins.

Ecology and distribution: epiphytic, lotic and lentic brackish waters, typically considered euryhaline. Cited in different 

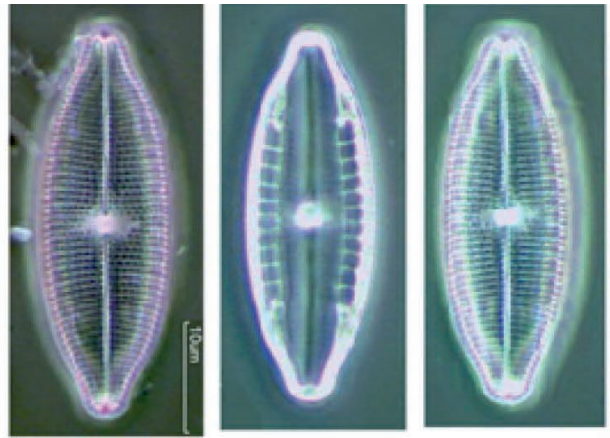

$1-5$
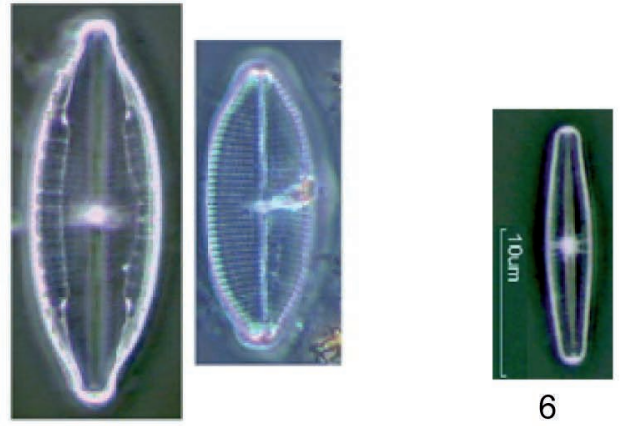

6

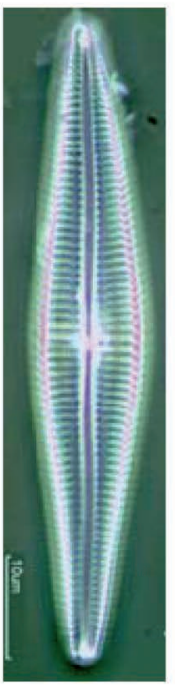

7

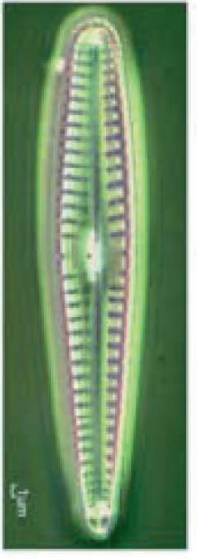

8-9

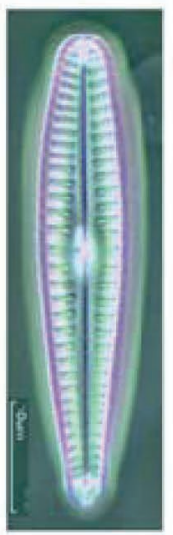

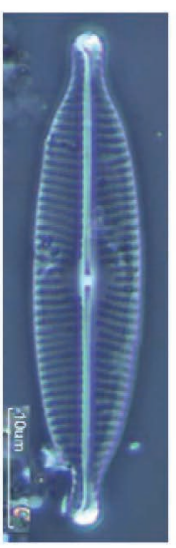

10
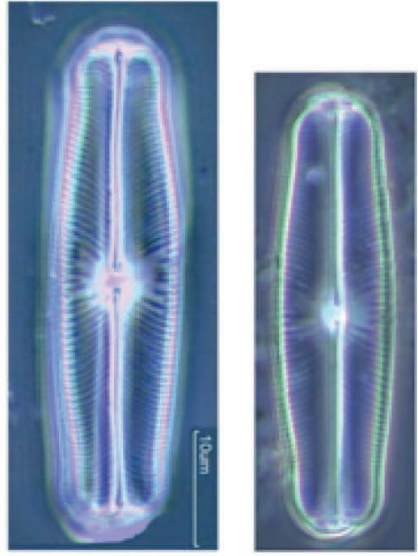

$11-12$

Fig. 5. Subdominant species (abundance > 1\%) LM: x1000. Images 1-12: 1-5, Mastogloia smithii; 6, Achnanthidium minutissimum; 7, Gomphonema gracile; 8-9, Gomphonema angustum; 10, Navicula rostellata; 11-12, Sellaphora pupula. Scale bar: 10 um.

water bodies of the Spanish Mediterranean coast. In this study, described in the three lakes (Table 4).

Order: Naviculales

Family Naviculaceae Kützing

Navicula cryptotenella Lange-Bertalot [LM: Fig. 3: 26-29]

(Navicula cryptotenella Lange-Bertalot in Krammer \& Lange-Bertalot, 1985: 62; pl. 18, fig. 22-23; pl. 19, fig. 1-10, pl. 27 , fig. 1,4)

Navicula radiosa var. tenella (Brébisson) Van Heurck, 1885

Navicula radiosa var. tenella (Brébisson) Cleve \& Möller, 1879

Navicula tenella Brébisson ex Kützing, 1849

Length 17.4-20.6 $\mu \mathrm{m}$, breadth 4.5-5.7 $\mu \mathrm{m}$. Valves lanceolates with acute apices slightly rounded, valve narrowly axial and slightly wider in the centre. Filiform raphe. Radial striae in the center, parallel or slightly convergent near the margin, usually with a shorter central stria.

Ecology and distribution: benthic, alkalophilic, freshbrackish, oligo-eutrophic- $\beta$-mesosaprobic waters. Broad distribution. In this study, it was observed in the epiphyton of CNP1 and was abundant in that of MFPNS (less present in its sediment) (Table 4).
Navicula seibigii Lange-Bertalot [LM: Fig. 3: 32-34; SEM: Fig. 6: 5a, b]

(Navicula seibigii, Lange-Bertalot, 1991)

Length 10-14.6 $\mu \mathrm{m}$, breadth 3.4-4 $\mu \mathrm{m}$. Linear-elliptical valves with rounded apices. Filiform raphe with marked central nodules. Axial area narrow-linear, central area irregular with a central-spaced stria on both sides. Bluntly striae, radial pores distribution in the center and parallel-convergent at the ends, striae do not reach the apices. SEM showed a polar raphe fissure and apical pores along the margin.

Ecology and distribution: eutrophic. In this study, it was observed in the sediment of CNP3 (Table 4).

Navicula wiesneri Lange-Bertalot [LM: Fig. 3: 30-31]

(Navicula wiesneri Lange-Bertalot, 1993: 140; pl. 41, fig. 23-27; pl. 42, fig. 3-6)

Navicula beufleri f. minuta Grunow, 1880

Length 14.6-17.7 $\mu \mathrm{m}$, breadth 4.9-5.4 $\mu \mathrm{m}$. Elliptic-lanceolated valves, with acute to slightly rounded apices. Filiform raphe, with central nodules. Axial area very narrow, small central zone. Marked striae, radial distribution in the center and changed to slightly convergent at the ends, $13-15 / 10 \mu \mathrm{m}$. 
Ecology and distribution: alkalophilic, eutrophic, freshbrackish waters. In this study only found in the sediment of MFPNS (Table 4).

Navicula sp. Bory de Saint-Vincent [LM: Fig. 3: 30-31]

(Bory de Saint-Vincent, J.B.G.M, 1822)

Valves lanceolate with rounded apices and dense, fine, barely marked striae 19-21/10 $\mu \mathrm{m}$. Axial area very narrow, small, rounded central area. Centric, filiform, straight raphe, with proximal ends slightly bent to one side and marked central nodules. Parallel striations at the ends and striae slightly shorter and radial in the center.

Ecology and distribution: in this study, it was observed in the sediment of CNP3 (Table 4).

Seminavis pusilla (Grunow) E.J. Cox \& G. Reid [LM: Fig. 3: 12-15; SEM: Fig. 6:3]

(Seminavis pusilla (Grunow) E.J. Cox \& G. Reid, 2004: 60)

Navicymbula pusilla K. Krammer, 2003

Navicella pusilla (Grunow) Krammer, 1997

Cymbella pusilla Grunow in A. Schmidt \& al., 1885

Length 26-31.1 $\mu \mathrm{m}$, breadth 5.4-6.6 $\mu \mathrm{m}$. Valves moderately dorsiventral, with a convex dorsal margin and a ventral margin slightly convex in the center. Rounded ends. Raphe almost central, straight with the distal fissures curved towards the ventral margin and proximal ends towards the dorsal margin, central nodules marked. Thin hyaline area along the axial axis, with irregular margins and slightly wider at the center. Marked striae, $16-17 / \mathrm{m}$ (dorsal and ventral), parallel at the ends and radial in the center (alternance of short and long striae). Pores distribution visible by SEM.

Ecology and distribution: temperate, epicontinental coastal waters (Gemain, 1981). In this study was abundant mainly in the epiphyton of the three study lakes (Table 4, Fig. 2).

Order Rhopalodiales

Family Rhopalodiaceae (Karsten) Topachevs'kyj \& Oksiyuk

Rhopalodia gibba var. gibba (Ehrenberg) O. Muller [LM: Fig. 4: 1-2; SEM: Fig. 7: 3a, b]

(Rhopalodia gibba (Ehrenberg) Otto Müller, 1895: 65, pl. 1: figs 15-17)

Rhopalodia gibba var. ventricosa (Kützing) Mayer, 1913

Epithemia ventricosa Kützing, 1844

Cells with dorsiventral valves, wider dorsally in the center, sharply curved hook-shaped ends. Marginal raphe-system on the dorsal side. Ventral margin straight, dorsal margin bent in the central area, usually has a small nick in the middle marking the position of the proximal raphe endings. Parallel costae in the center and radial at the ends with two rows of pores between transapical costae.

Ecology and distribution: periphytic, alkalophilic, freshbrackish, eutrophic- $\beta$-mesosaprobic waters. In this study, it was observed mainly in the epiphyton of CNP3 and MFPNS (Table 4, Fig. 2).
Family Stauroneidaceae D.G. Mann

Craticula halophila (Grunow ex Van Heurck) Mann [LM: Fig. 1: 20-23]

(Craticula balophila (Grunow) D.G.Mann in Round, Crawford \& Mann, 1990: 666)

Navicula balopbila (Grunow) Cleve, 1894

Navicula cuspidata var. halophila Grunow, 1885

Lenght 34-47 $\mu \mathrm{m}$, breadth 8-9.1 $\mu \mathrm{m}$. Valves lanceolaterhomboidal with narrow rounded apices, sometimes slightly cuneate. Raphe straight, filiform without central nodules, narrowly linear axial area, barely wider in the center. Striae fine and regular, $20-21 / 10 \mu \mathrm{m}$, nearly parallel in the center, convergent at the ends.

Ecology and distribution: alkalophilic, brackish springs and lakes, eutrophic- $\alpha$-mesosaprobic waters. According to Lange-Bertalot (2001), this diatom is less common in coastal brackish water bodies. However, it has been cited in coastal Mediterranean wetlands (Trobajo, 2005). In this study, it was found mainly in CNP1 and also CNP3 (Table 4).

Order Thalassiophysales

Family Catenulaceae Mereschkowsky

Halamphora bullatoides [LM: Fig. 3: 1-4; SEM: Fig. 6: 1a1b]

(Halamphora bullatoides (Hohn \& Hellerman) Levkov, 2009: 176; pl. 87, figs. 23-36)

Amphora bullatoides Hohn \& Hellermann, 1963

Lenght 21.7- $26 \mu \mathrm{m}$, breadth 3.8-5.4 $\mu \mathrm{m}$. Valves dorsiventral. Raphe straight, more or less central. Ventral margin slightly convex in the center. Subcapitate apices, bent towards the ventral margin. Marked parallel striations 17-19 dorsal / 10 microns, formed by 2-3 pore lines visible by SEM. Ventral striae visible only by electron microscopy, formed by a single row of pores. By light microscopy, it can be seen a shaded hyaline area in the centre.

Ecology and distribution: in this study, it was observed mainly in the sediment of CNP3 and MFPNS (Table 4).

Halamphora cf. sydowii [LM: Fig. 3:5-11; SEM: Fig. 6: 2a, b] (Halamphora sydowii (Cholnoky) Levkov, 2009: 232; pl. 105, fig. 7-11; 20-25; pl. 242, fig. 1-4)

Amphora sydowii Cholnoky, 1963

Lenght 24.6-30 $\mu \mathrm{m}$, breadth 5.4-7.1. Valves dorsiventral, with subcapitate ends at the dorsal margin. Ventral margin straight. Ventral-lateral linear raphe, axial narrowly area. Marked parallel dorsal striae, 16-18/10 $\mu \mathrm{m}$. By light microscopy, a different puncta pattern is observed in the area near the raphe, changing from a single broad row in the dorsal area to two thin pores rows, and longitudinal prolongations parallel to the raphe. Ventral striae short, parallel at the ends, slightly radial in the center, reaching the proximal ends of the raphe and leaving a hyaline central area. SEM microscopy showed that they are composed by a single transverse punctum. 

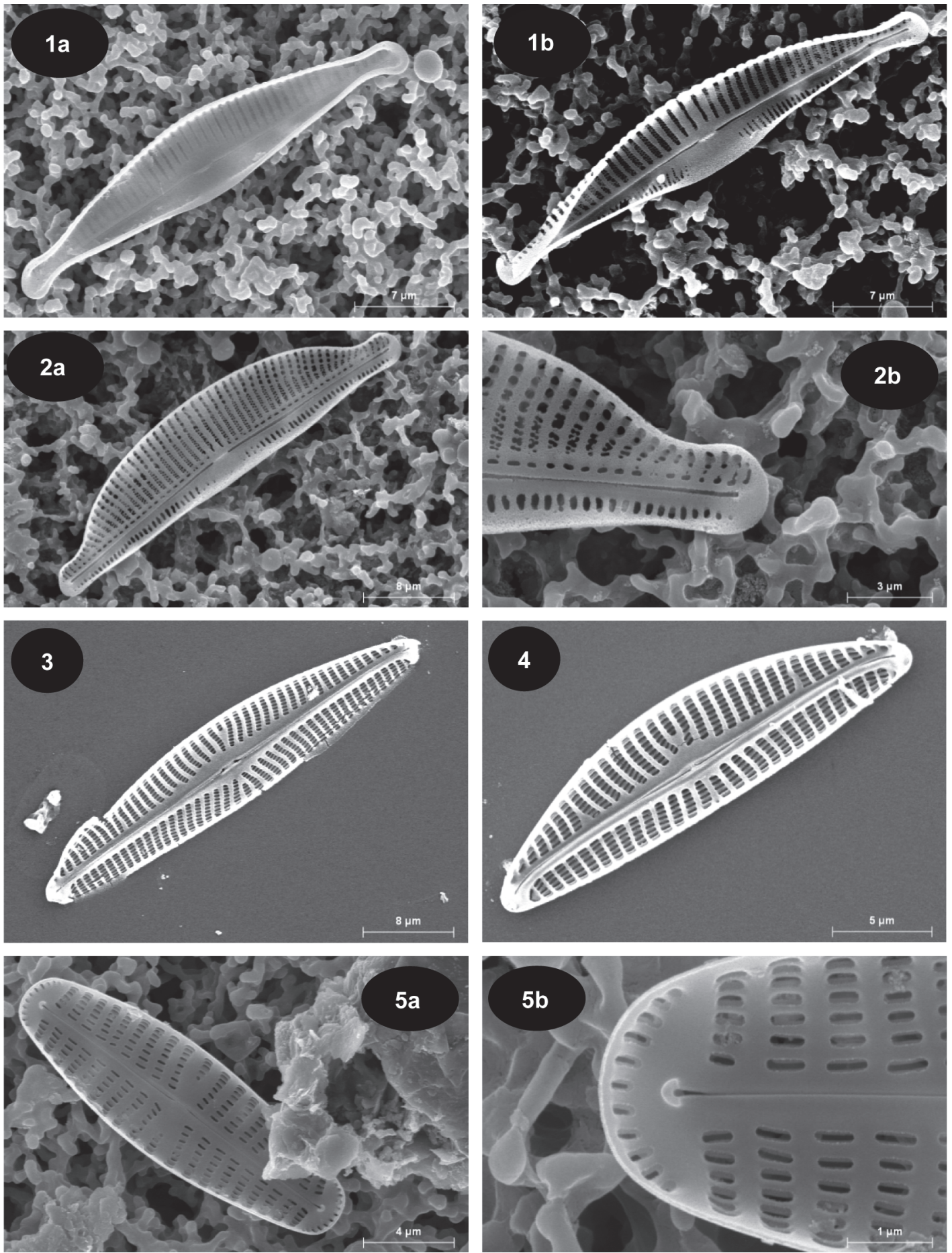

Fig. 6. Electron microscope images (SEM). Images 1a-5b: 1a, b, Halamphora bullatoides (internal view); 2a, Halamphora cf. sydowii; 2b, apex detail; 3, Seminavis pusilla; 4, Encyonema sp.; 5a, Navicula seibigii; 5b, Apex details.

Ecology and distribution: characteristic specie of brackish waters. In this study, it was observed in the three study lakes, being abundant in the sediment of CNP3 (Table 4, Fig. 2).

Class Mediophyceae

Order Thalassiosirales

Family Stephanodiscaceae Glezer \& Makarova
Cyclotella meneghiniana Kützing [LM: Fig. 3: 51-54; SEM: Fig. 7: 1]

(Cyclotella meneghiniana Kützing, 1844: 50, pl. 30: fig. 68) Cyclotella kutzingiana var. meneghiniana (Kützing) Brun, 1880

Stephanocyclus meneghiniana (Kützing) Skabichevskii, 1975

Cylindrical cells, circular valves and cell diameter of 6.2$28.3 \mu \mathrm{m}$. Valvar surface slightly undulating, coarse striations 6- 

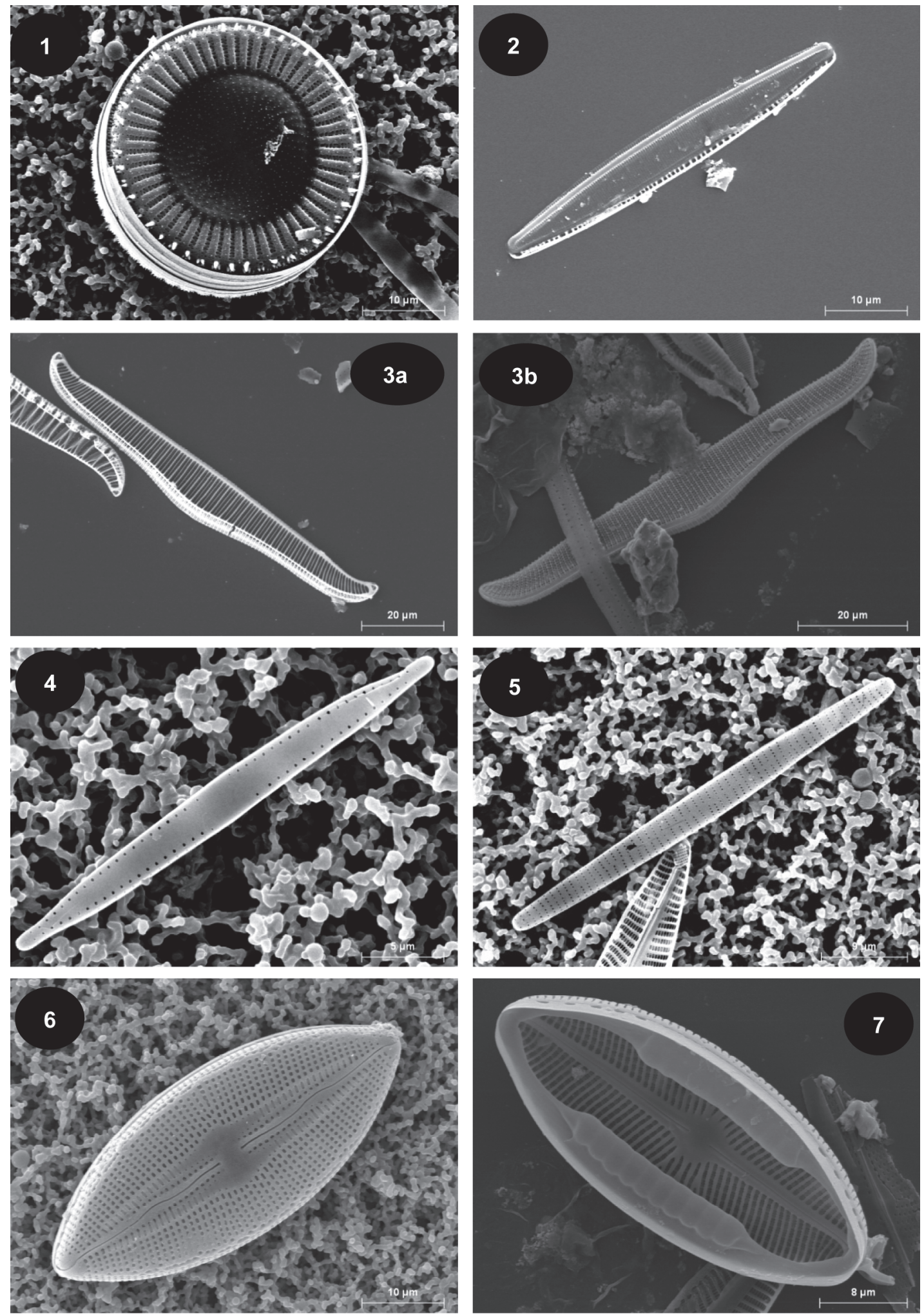

Fig. 7. Electron microscope images (SEM). Imges 1-7: 1, Cyclotella meneghiniana; 2, Nitzschia pusilla; 3a, Rhopalodia gibba var. gibba (internal view), 3b, external valve view; 4, Fragilaria gracilis (internal view); 5, Fragilaria famelica var. famelica; 6, Mastogloia braunii; 7, Mastogloia elliptica (inner view).

$12 / 10 \mu \mathrm{m}$, composed by two rows of pores, which form a ring at the valve contour (SEM). Central region smooth or slightly undulated, fine radial striae, 1-4 fultoportulae visibles under light microscope. Small peripheral spines visibles by SEM.
Ecology and distribution: tycoplanktonic, alkalophilic, halophilic, eutrophic- $\alpha$-mesosaprobic waters. Broad distribution. Frequently cited in the Iberian Peninsula. In this study, it was observed in MFPNS and CNP1 (Table 4). 


\section{DISCUSSION}

The diatom indices SPI, BDI and CEC are widely used to assess water quality, mainly in rivers, both in Europe and the Iberian Peninsula, and only recently their suitability for lentic aquatic systems has been tested (Blanco \& al., 2004; CejudoFigueiras \& al., 2010). The TDIL index was specifically made to be applied in shallow lakes of Central Europe (Hungary) (Stenger-Kovács \& al., 2007). However, coastal water bodies have higher salinity ranges and a different morphology and watershed impacts. In the present study, several problems were detected when these indices were tested for coastal shallow lakes. The main pitfall was the already limited knowledge gathered about the diatom flora and their ecological requirements in coastal Mediterranean standing waters (Trobajo, 2005; Cantoral-Uriza \& Aboal, 2008). In our study, the effectiveness of the indices depended on the number of species assessed for each index with respect to the total species recorded and the suitability of the weight assigned to each species. For instance, several of the dominant species in this study, which have been also reported in other Mediterranean water bodies (e.g. Mastogloia spp., Tomàs, 1982), were omitted by the database of the indices tested. In addition, one of the most representative species in our study, Seminavis pusilla, was only included by the SPI and TDIL indices. This could also explain the observed discrepancy between indices, as a result of the different listed and weight given to diatom species by every single index (Table 3 ). The fact that taxonomy challenged the identification of some species, such as Encyonema sp., which was dominant in CNP1 and MFPNS, constitutes an additional problem to cope with the finest taxonomic accuracy required by the indices. Some of these problems have been also described by Blanco \& al. (2004), when they used the SPI and BDI indices for the water quality evaluation of some inland shallow lakes of the Northwest Iberian Peninsula. Nevertheless, these authors found a good correlation between these indices and the lakes trophic status, based on the distribution of diatom abundances and trophic preferences. Therefore, to use more extensively diatom indices in coastal lentic systems, further studies should be carried out on the description and autoecology of their characteristic diatom flora.

The ecological requirements of the algal species may vary depending on the eco-region and thus the use of any diatom index must be calibrated for different ecosystems (Álvarez \& al., 2011, 2012). The design of new and specific indices for different eco-zones is a new approach (e.g. DDI index, Álvarez-Blanco et al., 2012). This alternative approach, even though, is time and investment consuming might be more accurate for the ecological evaluation of coastal water bodies of the Mediterranean zone.

It is remarkable that a large number of the recorded diatom species in this study (38 in total, highlighted in bold in Table 4) have been also cited by other authors in coastal Mediterranean Iberian environments (lagoons, marshes, ponds, river mouths and streams) (Tomàs, 1982; Aboal, 1989; Trobajo, 2005; Cantoral-Uriza \& Aboal, 2008; Rovira \& al., 2009). This set of species could be a starting point for further studies, in order to define their role as bioindicators in coastal water bodies and for the design of new diatom indices. Therefore, more studies on the ecology and algal flora are needed to characterize, evaluate and implement the WFD in these ecosystems.

In general, the diatom species found in this study had a wide tolerance range to several physico-chemical variables, which agree with the dynamic nature of coastal water bodies, adapted, for instance, to water level and environmental changes (Trobajo, 2005; Della Bella \& Mancini, 2009). The limnological variables evaluated in the present study complemented the diagnosis given for the diatom indices and resulted especially helpful to discriminate between possible water quality status (Tables 2,3 ). This result agrees with that described by other authors that argued about the use of several metrics for the correct water quality evaluation of shallow lakes (Kitner \& Poulícková, 2003; Moss \& al., 2003).

In conclusion, our results suggest that diatom bioindication could be a useful tool for the determination of the ecological status of coastal shallow lakes, together with environmental metrics. However, it would be necessary modify or create new indices based specifically on the autecology and distribution of diatom species in the gradient of environmental conditions characteristic of the Mediterranean eco-zone. Therefore, it is important to gather more information about the composition and ecology of the microflora and diatoms of these ecosystems.

\section{ACKNOWLEDGEMENTS}

We are grateful to J. Armengol, C. Olmo-Rodríguez, R. Ortells, M. Anton-Pardo and our collaborators for their invaluable help and support during field and laboratory work. We also thank Dr. S. Blanco for his help in the final identification of some diatom species. This work was partially supported by a Ministry of Science and Innovation project (CLG2008-03760BOS) and carried out in collaboration with Laboratorios Tecnológicos de Levante.

\section{REFERENCES}

Aboal, M. 1989. Aportaciones al conocimiento de las algas del SE de España. IV. Las Diatomeas (Bacillariophyceae). Acta Botánica Malacitana 14: 13 40.

Álvarez-Blanco, I., Cejudo-Figueiras, C., Bécares, E. \& Blanco, S. 2011. Spatiotemporal changes in diatom ecological profiles: implications for biomonitoring. Limnology, 12: 157-168.

Álvarez-Blanco, I., Blanco, S., Cristina Cejudo-Figueiras, C. \& Bécares, E. 2012. The Duero Diatom Index (DDI) for river water quality assessment in NW Spain: design and validation. Environmental Monitoring and Assessment. DOI 10.1007/s10661-012-2607-z.

APHA. 1992. Standard Methods for the examination of water and wastewater. American Public Health Association. Washington D.C.

Blanco, S., Ector, L. \& Bécares, E. 2004. Epiphytic diatoms as water quality indicators in Spanish shallow lakes. Vie Milieu-Life and Environment 54: 71-79.

Blanco, S., Ector, L., Huck, V., Monnier, O., Cauchie, H. M., Hoffmann L.\& Bécares, E. 2008. Diatom assemblages and water quality assessment in the Duero Basin (NW Spain). Belgian Journal of Botany 141:39-50.

BOE. 2008. Instrucción de Planificación Hidrológica. ORDEN ARM/ 2656/2008, de 10 de septiembre. Boletín Oficial del Estado 229: 38472 38582.

Cantoral-Uriza, E.A. \& Aboal, M. 2008. Diatomeas (Bacillariophyceae) del marjal Oliva-Pego (Comunidad Valenciana, España). Anales del Jardín Botánico de Madrid 65: 111-128.

CEDEX. 2010a. Establecimiento de condiciones hidromorfológicas y físicoquímicas específicas de cada tipo ecológico en masas de agua de la categoría lagos en aplicación de la Directiva Marco del Agua v 1.0 (Informe técnico). Centro de Estudios y Experimentación de Obras Públicas. Madrid. $70 \mathrm{pp}$. 
CEDEX. 2010b. Establecimiento de condiciones de referencia y valores frontera entre clases de estado ecológico en masas de agua de la categoría lago para los elementos de calidad "composición, abundancia y biomasa de fitoplancton" y "composición, y abundancia de otro tipo de flora acuática, en aplicación de la directiva marco del agua (Informe técnico). Centro de Estudios y Experimentación de Obras Públicas. Madrid. 62 pp.

Cejudo-Figueiras, C. 2011. Monitorización de los ecosistemas dulceacuícolas mediante métricas basadas en diatomeas. Tesis doctoral. Universidad de León. 108 pp.

Cejudo-Figueiras, C., Blanco, S., Álavarez-Blanco, I., Ector, L. \& Bécares, E. 2010. Nutrient monitoring in Spanish wetlands using epiphytic diatoms. Vie E Milieu - Life and Environment 60(2): 89-94.

CEMAGREF. 1982. Étude des méthodes biologiques d'appréciation quantitative de la qualité des eaux. Rapport Q.E. Lyon-A.F. Bassin Rhône-Méditeranée-Corse. 218 pp.

Confederación Hidrográfica del Duero. 2010. Guía de diatomeas de la cuenca del Duero. Ministerio de Medio Ambiente. 207 pp.

Della Bella, V. \& Manzini, L. 2009. Freshwater diatom and macroinvertebrate diversity of coastal permanent ponds along a gradient of human impact in a Mediterranean eco-region. Hydrobiologia 634: 25-41.

Descy, J.P. \& Coste, M. 1990. Utilisation des diatomées benthiques pour l'évaluation de la qualité des eaux courantes. (Rapport final). Contrat CEE B-71-23 UNECED-NAMUR, CEMAGREF. Bordeaux.

DOCE. 2008. Commission Decision of 30 Octuber 2008, establishing, pursuat to Directive 2000/60/EC of the European Parliament and the Council, the values of the Member State monitoring system classifications as a result of the intercalibration exercise. DOCE $n^{\circ} \mathrm{L} 332$ : 20-44, de 10 de diciembre de 2008. Bruselas.

European Parliament \& The Council of the European Union. 2000. Directive 2000/60/EC of the European Parliamrnt and of the Council establishing a framework for the Community action in the field of water policy. Official Journal of the European Communities, L327: 1-72.

Germain, H. 1981. Flore des diatomées, eaux douces Es saumatres. Société nouvelle des editions Boubée. Paris. 444 pp.

Kitner, M. \& Poulícková, A. 2003. Littoral diatoms as indicators for the eutrophication of shallow lakes. Hydrobiologia 506-509:519-524.

Krammer, K. \& Lange-Bertalot, H. 1991a. Bacillariophyceae: Centrales, Fragilariaceae, Eunotiaceae. In: \&tl, H., Gerloff, J., Heynig, H. \& Mollenhauer, D. (eds.), Süsswasserflora von Mitteleuropa. Band 2, 3 Teil. Gustav Fischer Verlag. Stuttgart-Jena. 576 pp.

Krammer, K. \& Lange-Bertalot H. 1991b. Bacillariophyceae: Achnanthaceae, Kritische Ergänzungen zu Navicula (Lineolatae) und Gomphonema Gesamtliteraturverzeichnis. Teil 1-4. In: \&tl, H., Gärtner, G., Gerloff, J., Heynig, H. \& Mollenhauer, D. (eds.), Süsswasserflora von Mitteleuropa. Band 2, 4 Teil. Gustav Fischer Verlag. Stuttgart, Jena. 436 pp.

Krammer, K. \& Lange-Bertalot, H. 1997a. Bacillariophyceae: Naviculaceae. In: \&tl, H., Gerloff, J., Heynig, H. \& Mollenhauer, D. (eds.), Süsswasserflora von Mitteleuropa. Band 2, 1 Teil. Gustav Fischer. Jena-SttutgartLübeck-Ulm. 876 pp.

Krammer, K. \& Lange-Bertalot, H. 1997b. Bacillariophyceae: Bacillariaceae, Epithemiaceae, Surirellaceae. In: \&tl, H., Gerloff, J., Heynig, H. \& Mollenhauer, D. (eds.), Süsswasserflora von Mitteleuropa. Band 2, 2 Teil. Gustav Fischer. Jena-Sttutgart-Lübeck-Ulm. 610 pp.

Krammer, K. \& Lange-Bertalot, H. 2000. Bacillariophyceae: English and French translation of the keys. In: Büdel, B., Gärtner, G., Krienitz, L. \& Lokhorst, G. M. (eds.), Süsswasserflora von Mitteleuropa. Vol. 2, part 5. Engl. transl.: N. Bate \& A. Podzorksi. French transl.: J. Bukowska, M. Michel \& J. Prygiel. Spektrum Akademischer Verlag GmbH. Heidelberg-Berlin. 310 pp.
Lange-Bertalot, H. 2001. Navicula sensu estricto. 10 genera separated from Navicula sensu lato. Frustulia. Diatoms of Europe. In: lange-Bertalot, H. (eds.), Diatoms of the Europe Inland waters and comparable habitats. Vol. 2. A.R.G. Ganter Verlag K.G. 526 pp.

Lecointe, C., Coste, M., Prygiel. J. 1993. OMNIDIA software for taxonomy, calculation of diatom indices and inventories management. Hydrobiologia 269/270: 509-513.

Lenoir, A. \& Coste, M. 1996. Development of a practical diatom index of overall water quality applicable to the French national water Board network. In: Use of Algae for monitoring rivers II. Studia Student G.m.b.H. (ed.): 29-43. Innsbruck.

Moss, B., Stephen, D., Álvarez, C., Bécares, E., Van De Bund, W., Collings, S.E., Van Donk, E., De Eyto, E., Feldmann, T., Fernández-Aláez, C., Fernández-Aláez, M., Franken, R.J.M., García-Criado, F., Gross, E., Gyllström, M., Hansson, L.A., Irvine, K., Järvalt, A., Jensen, J.P., Jeppesen, E., Kairesalo, T., Kornijow, R., Krause, T., Künnap, H., Laas, A., Lill, E., Lorens, B., Luup, H., Miracle, M.R., Nõges, P., Nõges, T., Nykänen, M., Ott, L., Peczula, W., Peeters, E.T.H.M., Phillips, G., Romo, S., Russell, V., Salujõe, J., Scheffer, M., Siewertsen, K., Smal, H., Tesch, C., Timm, H., Tuvikene, L., Tonno, I., Virro, T., Vicente, E. \& Wilson D. 2003. The determination of ecological status in shallow lakes - a tested system (ECOFRAME) for implementation of the European Water Framework Directive. Aquatic Conservation: Marine and Freshwater Ecosystems 13: 507-549.

Moss, B., Stephen, D., Balayla, D., Bécares, E., Collings, S.E., FernándezAláez, C., Fernández-Aláez, M., Ferriol, C., García, P., Gomá, J., Gyllström, M., Hansson, L.-A., Hietala, J., Kairesalo, T., Miracle, M.R., Romo, S., Rueda, J., Russell, V., Ståhl-Delbanco, A., Svensson, M., Vakkilainen, K., Valentín, M., Van De Bund, W. J., Van Donk, E., Vicente E. \& Villena, M.J. 2004. Continental-scale patterns of nutrient and fish effects on shallow lakes: synthesis of a pan-European mesocosm experiment. Freshwater Biology 49: 1633-1649.

Prygiel, J. \& Coste, M. 2000. Guide methodologique pour la mise en oeuvre de I'Indice Biologique Diatomees NF T 90-354. Agence de I'Eau ArtoisPicardie-Cemagref, Bordeaux. 134 pp.

Romo, S., Villena, M.J., Sahuquillo, M., Soria, J.M., Giménez, M., Alfonso, T., Vicente, E. \& Miracle, M.R. 2005. Response of a shallow Mediterranean lake to nutrient diversion: does it follow similar patterns as in northern shallow lakes? Freshwater Biology 50: 1706-1717.

Rovira, L., Trobajo R. \& Ibáñez, C. 2009. Periphytic diatom community in a Mediterranean salt wedge estuary: the Ebro Estuary (NE Iberian Peninsula). Acta Botanica Croatica 68 (2): 285-300.

Stenger-Kovács, C., Buezkó, K., Hajnal, E. \& Padisák, J. 2007. Epiphytic, litoral diatoms as bioindicators of shallow lake trophic status: Trophic Diatom Index for Lakes (TDIL) developed in Hungary. Hydrobiologia 589: 141-154.

Tomàs, X. 1982. El género Mastogloia en los sistemas acuáticos del litoral mediterráneo español. Collectanea Botanica 13 (2): 929-944.

Trobajo, R. 2005. Ecological analysis of periphytic diatoms in Mediterranean coastal wetlands (Empordà wetlands, NE Spain). Tesis doctoral. Universitat de Girona. $171 \mathrm{pp}$.

UNE-EN 13946. 2004. Calidad del agua. Guía para el muestreo en rutina y el pretratamiento de diatomeas bentónicas de ríos.

Zimba, P.V. \& Hopson, M.S. 1997. Quantification of epiphyte removal efficiency from submerged aquatic plants. Aquatic Botany 58: 173-179.

Associate Editor: Javier Fuertes Received: 5-IV-2013 Accepted: 5-III-2014 